\title{
Ekstrak Bawang Putih Siung Tunggal terhadap Aktivitas Enzim Lipoprotein Lipase pada Tikus dengan Diet Tinggi Lemak
}

\author{
Juliana Veronica Brouwer ${ }^{1}$, R. Bambang Wirjatmadi ${ }^{2}$, Merryana Adriani ${ }^{3}$ \\ Mahasiswa Magister Kesehatan Masyarakat Universitas Airlangga Surabaya ${ }^{1}$ \\ Departemen Gizi Kesehatan M asyarakat Universitas Airlangga Surabaya ${ }^{2,3}$ \\ JI. DR. Ir. H. Soekarno, Mulyorejo, Kota Surabaya, Jawa Timur, 60115 \\ * e-mail: julianabrouwer15@gmail.com
}

\begin{abstract}
Abstrak
Mengkonsumsi makanan tinggi lemak akan berdampak buruk bagi kesehatan manusia, seperti yang kita ketahui bahwa dengan konsumsi makanan-makanan yang mengandung tinggi kolesterol maka, resiko terjadi obesitas sangat tinggi. Resiko obesitas sangat dekat dengan kandungan lemak yang tinggi di dalam darah yang biasa disebut dengan hipertrigliserida Terapi herbal tradisional merupakan terapi alternatif yang dapat digunakan untuk mencegah dan menurunkan kadar trigliserida di dalam darah. Salah satu pilihan terapi yang digunakan adalah bawang putih siung tunggal (Allium Sativum Linn.). Bawang putih siung tunggal memiliki kandungan antioksidan yang kuat yaitu flavonoid, apabila dengan rutin mengkonsumsinya dapat menurunkan kadar trigliserida didalam darah sehingga resiko penyakit degeneratif dapat dikurangi. Flavonoid adalah senyawa golongan polifenol. flavonoid memiliki kemampuan sebagai antitrigliserida. Flavonoid bekerja pada banyak enzim dalam pembentukan kolesterol atau trigliserida, salah satunya adalah enzim lipoprotein lipase. Sehingga, apabila aktivitas enzim lipoprotein lipase meningkat, maka proses pembentukan trigliserida melalui mekanisme jalur eksogen di pembuluh darah terhambat sehingga kadar trigliserida dapat menurun. Penelitian ini menggunakan jenis penelitian eksperimental laboratorium dengan design Pre test- Post test Controlled. Menggunakan 5 kelompok dengan masing-masing kelompok menggunakan 5 ekor tikus. uji Paired T-Test menunjukkan bahwa terdapat perbedaan aktivitas enzim lipoprotein lipase dengan nilai signifikansi $(p<0.05)$ sedangkan pada uji Manova, nilai signifikansi yang didapatkan adalah (p. <0.05). Berdasarkan hasil penelitian, dapat disimpulkan bahwa pemberian ekstrak bawang putih siung tunggal dapat meningkatkan aktivitas dari enzim lipoprotein lipase
\end{abstract}

Kata Kunci: Hiperkolesterol, Lipoprotein Lipase, Flavonoid, Trigliserida

\section{Single Cloves Garlic Extract in Enzyme Lipoprotein Lipase Activity of White Rats with High Fat Diet}

\begin{abstract}
Consuming high-fat foods will have a negative impact on human health, as we know that by consuming foods that contain high cholesterol, the risk of obesity is very high. The risk of obesity is very close to the high fat content in the blood which is commonly called hypertriglyceride. Traditional herbal therapy is an alternative therapy that can be used to prevent and reduce levels of triglycerides in the blood. One of the options of therapy used is a single clove garlic (Allium Sativum Linn.). Single clove garlic contain powerful antioxidant
\end{abstract}


Ekstrak Bawang Putih Siung Tunggal terhadap Aktivitas Enzim Lipoprotein...

Juliana Veronica Brouwer, R. Bambang Wirjatmadi, Merryana Adriani

flavonoids, when routine consumption can lower levels of triglycerides in the blood so that the risk of degenerative diseases can be reduced. Flavonoids are compounds, the polyphenols. flavonoids have the ability as a anticholesterol. Flavonoids work on many of the enzyme in the formation of cholesterol or triglycerides, one of which is the enzyme lipoprotein lipase. So, when increased lipoprotein lipase enzyme activity, then the process of the formation of triglycerides through exogenous pathway mechanism in obstructed blood vessels so that the levels of triglycerides may be declining. This research uses a type of experimental research laboratory with design Pre test - Post test Controlled. Using 5 groups with each group using 5 rats. test for Paired T-Test showed that there is a difference of enzyme activity of lipoprotein lipase with significance value $(p<0.05)$ while in Manova test, the value of significance is derived ( $p .<0.05)$. Based on the results of the research, it can be concluded that the granting of a single clove garlic extracts can increase the activity of the enzyme lipoprotein lipase

Keywords: Hyperkolesterolemia, Lipoprotein Lipase, Flavonoid, Tryglicerida

\section{PENDAHULUAN}

Dewasa ini kecenderungan peningkatan penyakit degeneratif semakin meningkat salah satunya adalah suatu kondisi yang dikatakan hipertrigliserida. Hipertrigliserida merupakan suatu keadaan dimana kadar trigliserida didalam darah mengalami peningkatan diatas angka ratarata nilai normal. Hipertrigliserida terjadi penimbunan visceral fat dan turunnya aktivitas enzim lipoprotein lipase di dalam darah (Golderg, 2001; Wresdiyati, 2006). Aktivitas dari enzim lipoprotein lipase berpengaruh terhadap metabolisme lemak (Unal, 2008).

Secara umum, penggunaan obat hipertrigliserida dapat mengendalikan dan menurunkan kadar trigliserida di dalam darah. Terapi herbal tradisional merupakan terapi alternatif yang dapat digunakan untuk mencegah dan menurunkan kadar trigliserida di dalam darah. Salah satu pilihan terapi yang digunakan adalah bawang putih siung tunggal (Allium Sativum Linn.). Bawang putih siung tunggal memiliki kandungan antioksidan yang kuat yaitu flavonoid, apabila dengan rutin mengkonsumsinya dapat menurunkan kadar trigliserida didalam darah sehingga resiko penyakit degeneratif dapat dikurangi.

Flavonoid adalah senyawa golongan polifenol. flavonoid memiliki kemampuan sebagai antikolesterol. Flavonoid bekerja pada banyak enzim dalam pembentukan kolesterol atau trigliserida, salah satunya adalah enzim lipoprotein lipase. Peran flavonoid tersebut adalah meningkatkan aktivitas enzim lipoprotein lipase yang akan meningkatkan hidrolisis trigliserida menjadi asam lemak dan gliserol untuk dilepaskan ke pembuluh darah. Sel-sel yang membutuhkan asam lemak dan gliserol 
akan membakar komponen-komponen tersebut dan menghasilkan energi, yaitu karbon dioksida $\left(\mathrm{CO}_{2}\right)$ dan air $\left(\mathrm{H}_{2} \mathrm{O}\right)$. Sehingga, apabila aktivitas enzim lipoprotein lipase meningkat, maka proses pembentukan trigliserida melalui mekanisme jalur eksogen di pembuluh darah terhambat sehingga kadar trigliserida dapat menurun (Pramono,2011).

Berdasarkan latar belakang diatas, maka peneliti melakukan penelitian lebih lanjut untuk mengetahui peningkatan aktivitas enzim lipoprotein lipase yang dapat mencegah terjadinya kejadian hipertrigliserida di dalam darah.

\section{BAHAN DAN METODE}

\section{Perlakuan Hewan Coba}

Penelitian ini adalah penelitian eksperimental laboratorium untuk mengetahui pengaruh pemberian ekstrak bawang putih siung tunggal (Allium Sativum Linn.) terhadap aktivitas enzim lipoprotein lipase pada tikus putih (Ratus Norwegicus strain Wistar) yang diberi diet tinggi lemak dengan rancangan Pre testPost test Controlled.

Hewan uji yang digunakan berupa 25 ekor tikus putih, jantan, usia sekitar 2 bulan, dengan berat $\pm 150-180$ gram. Hewan uji tersebut dibagi dalam 5 kelompok, yaitu: kelompok Kontrol negatif
(KN) hanya diberi pakan standar, kelompok kontrol positif (KP) diberi pakan standar dan diet tinggi lemak, kelompok perlakuan 1 (P1) diberi pakan standar, diet tinggi lemak dan ekstrak bawang putih siung tunggal dengan dosis $0.05 \mathrm{~g} /$ ekor/ hari, kelompok perlakuan 2 (P2) diberi pakan standar, diet tinggi lemak dan ekstrak bawang putih siung tunggal dengan dosis $0.1 \mathrm{~g} /$ ekor/ hari dan kelompok perlakuan 3 (P3) diberi pakan standar, diet tinggi lemak dan ekstrak bawang putih siung tunggal dengan dosis $0.2 \mathrm{~g} /$ ekor/ hari.. Masingmasing kelompok terdiri dari 5 ekor tikus. Penelitian ini berlangsung selama 28 hari. Tikus yang tidak mau makan dan minum serta mengalami penurunan keadaan fisik, dikeluarkan dari sampel penelitian.

\section{Perlakuan Tikus dengan Diet Tinggi Lemak}

Diet tinggi lemak yang digunakan untuk membuat tikus masuk dalam keadaan hipertrigliserida berupa campuran emulsi dari otak sapi 1,6 cc, kuning telur puyuh 0,3 cc dan glukosa 0,1 dengan dosis total sebanyak $2 \mathrm{cc} /$ ekor/ hari. Pengambilan darah tikus dilakukan sebanyak dua kali yaitu sebelum tikus diberi diet tinggi lemak dan setelah tikus diberi diet tinggi kolesterol. 
Ekstrak Bawang Putih Siung Tunggal terhadap Aktivitas Enzim Lipoprotein...

Juliana Veronica Brouwer, R. Bambang Wirjatmadi, Merryana Adriani

Pengujian Aktivitas Enzim Lipoprotein Lipase

Pengambilan sampel darah untuk menguji aktivitas enzim lipoprotein lipase dilakukan melalui vena lateralis ekor tikus. Kemudian darah dimasukkan kedalam tabung mikrosentrifugasi, didiamkan sampai terbentuknya serum darah. Supernatant diambil kembali endapannya. Edapan tersebut diberikan etanol dingin. Selanjutnya, dilakukan sentrifugasi untuk diambil lagi endapannya. Kemudian endapan ditambah dengan buffer fosfat pH6.8 dan disimpan pada suhu $-20^{\circ} \mathrm{C}$. Larutan enzim lipoprotein lipase ditambahkan dengan larutan substrat minyak zaitun dan larutan gum arabik, kemudian diinkubasi pada suhu $37^{\circ} \mathrm{C}$ selama 10 menit. Selanjutnya, campuran tersebut dididihkan didalam air mendidih selama kurang lebih 10 menit. Kemudian ditambahkan indicator fenolftalein dan selanjutnya dititrasi dengan natrium hidroksida $(\mathrm{NaOH}) \quad 0,1 \mathrm{~N}$ sampai terjadi warna merah muda ( Roslizawaty, 2016). Aktivitas enzim LPL diukur menggunakan rumus:

Alatitas $=\frac{N \text { NaOH } x V \text { NaOH } x T \times F p}{V E x t}$

( $\mathrm{N} \mathrm{NaOH}=$ Konsentrasi $\mathrm{NaOh} ; \mathrm{V} \mathrm{NaOH}=$ Volume $\mathrm{NaOH} ; \mathrm{T}=$ Temperatur Inkubasi; $\mathrm{Fp}=$ Faktor Pengenceran; VE $=$ Volume Enzim; $t=$ Waktu Inkubasi. Roslizawaty, 2016)

\section{Analisis Data}

Analisis data dilakukan dengan menggunakan uji Paired T-test untuk membandingkan aktivitas enzim lipoprotein lipase sebelum dan setelah dilakukan perlakuan. Lalu, akan dilanjutkan dengan MANOVA (Multivariate Analyses of Variance) untuk melihat perbedaan aktivitas enzim lipoprotein lipase antar kelompok perlakuan.

\section{HASIL}

\section{Analisis Aktivitas Enzim Lipoprotein Lipase Sebelum dan Setelah Perlakuan}

Tabel 1. Perbedaan rata-rata aktivitas enzim lipoprotein lipase sebelum dan setelah diberi ekstrak bawang putih siung tunggal pada tikus dengan diet tinggi lemak

\begin{tabular}{|c|c|c|c|c|}
\hline Kelompok & $n$ & $\begin{array}{c}\text { Sebelum Perlakuan } \\
\text { Mean } \pm \text { SD } \\
(\mu \mathrm{mol} / \mathrm{ml} / \mathrm{dl})\end{array}$ & $\begin{array}{c}\text { Setelah Perlakuan } \\
\text { Mean } \pm \text { SD } \\
(\mu \mathrm{mol} / \mathrm{ml} / \mathrm{dl})\end{array}$ & p. \\
\hline Kontrol Negatif & 5 & $0.878 \pm 0.037$ & $0.866 \pm 0.024$ & 0.631 \\
\hline Kontrol Positif & 5 & $0.853 \pm 0.026$ & $0.435 \pm 0.051$ & 0.000 \\
\hline Perlakuan 1 & 5 & $0.844 \pm 0.033$ & $0.878 \pm 0.021$ & 0.023 \\
\hline Perlakuan 2 & 5 & $0.864 \pm 0.035$ & $0.922 \pm 0.018$ & 0.036 \\
\hline Perlakuan 3 & 5 & $0.851 \pm 0.022$ & $0.968 \pm 0.012$ & 0.000 \\
\hline
\end{tabular}




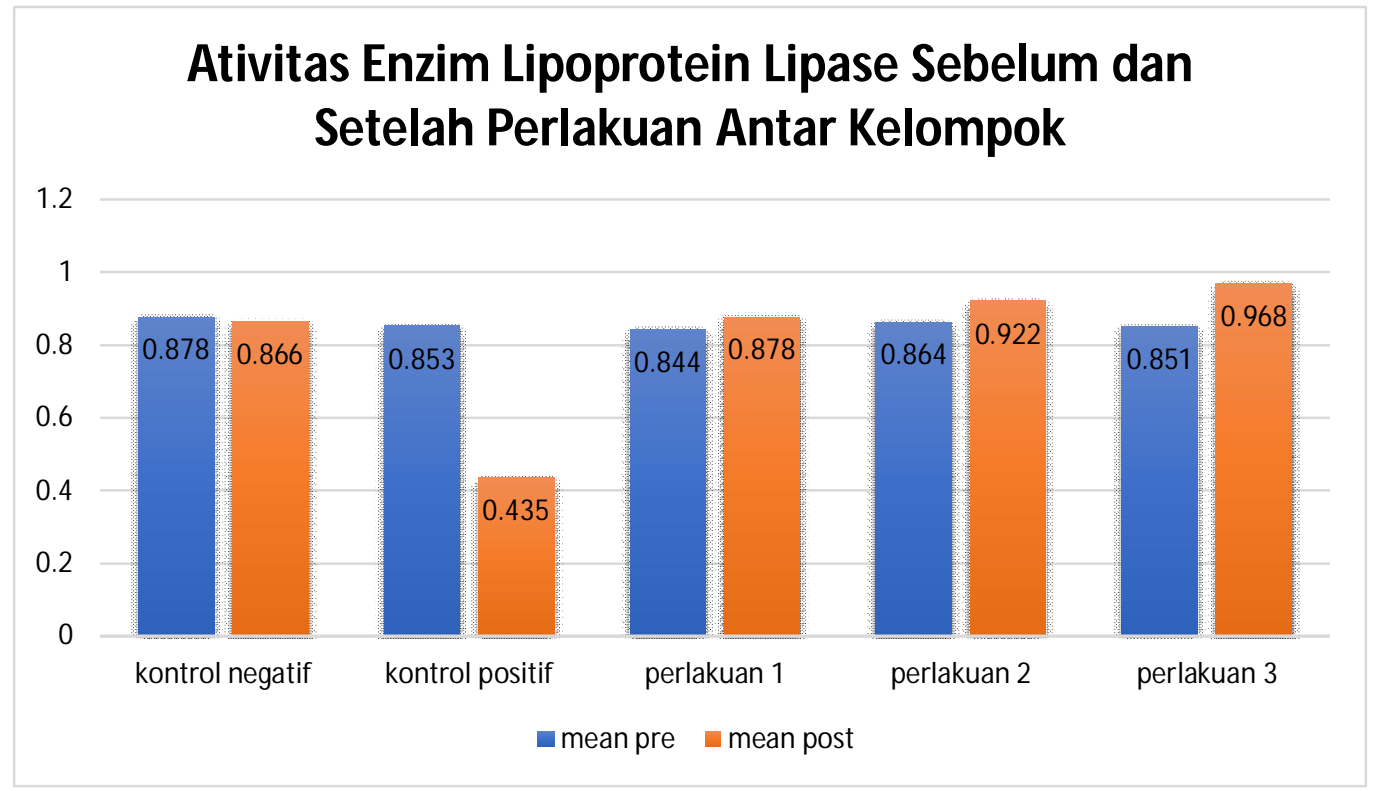

Gambar 1. Grafik aktivitas enzim lipoprotein lipase sebelum dan sesudah perlakuan antar kelompok

Berdasarkan uji Paired T-Test

menunjukkan bahwa terdapat perbedaan

aktivitas enzim lipoprotein lipase sebelum dan setelah pemberian perlakuan pada kelompok kontrol positif, kelompok perlakuan 1, kelompok perlakuan 2 dan kelompok perlakuan 3 dengan nilai signifikan $\mathrm{p}<0.05$. akan tetapi tidak terdapat perbedaan yang signifikan pada kelompok kontrol negatif yakni dengan nilai signifikan $p>0.05$.

\section{Hasil dan Analisis Aktivitas Enzim Lipoprotein Lipase}

Berdasarkan uji Manova, nilai signifikansi yang didapatkan adalah 0.000 (p. < 0.05). Artinya, terdapat perbedaan kadar trigliserida pada kelompok kontrol negatif, kontrol positif, perlakuan pertama, perlakuan kedua, dan perlakuan ketiga.

Aktivitas enzim lipoprotein lipase pada kelompok kontrol negatif yang dibandingkan dengan kelompok kontrol positif, Perlakuan 2 dan perlakuan 3 menunjukkan hasil yang signifikan $(p \varangle 0.05)$. Aktivitas enzim lipoprotein lipase pada kelompok kontrol positif yang dibandingkan dengan kelompok kontrol negatif, perlakuan 1, perlakuan 2 dan perlakuan 3 menunjukkan hasil yang signifikan $(p \varangle 0.05)$. Aktivitas enzim lipoprotein lipase pada kelompok perlakuan 1 dengan kelompok kontrol positif, perlakuan 2 dan perlakuan 3 menunjukkan hasil yang signifikan ( $p$. ४.05). Aktivitas enzim lipoprotein lipase pada kelompok perlakuan 2 dengan 
Ekstrak Bawang Putih Siung Tunggal terhadap Aktivitas Enzim Lipoprotein...

Juliana Veronica Brouwer, R. Bambang Wirjatmadi, Merryana Adriani

kelompok kontrol negatif, kelompok kontrol positif, perlakuan 2 dan perlakuan 3 menunjukkan hasil yang signifikan ( $p$. < 0.05). Aktivitas enzim lipoprotein lipase pada kelompok perlakuan 3 dengan kelompok kontrol negatif, kelompo kontrol positif, perlakuan 1 dan perlakuan 2 menunjukkan hasil yang signifikan $(\mathrm{p} \varangle 0.05)$.

\section{PEMBAHASAN}

Pada penelitian ini, berdasarkan hasil analisis statistik terlihat perbedaan hasil aktivitas enzim lipoprotein lipase sebelum dan setelah dilakukan perlakuan yaitu pada kelompok kontrol positif, perlakuan 1, perlakuan 2 dan perlakuan 3 dengan nilai signifikansi (p. $<0.05)$. sedangkan untuk kelompok kontrol negatif tidak terjadi perbedaan yang signifikan. Melalui hasil dari kelompok kontrol positif dapat diketahui bahwa dengan pemberian diet tingi kolesterol dapat menurunkan aktivitas dari enzim lipoprotein lipase, sedangkan pada kelompok perlakuan 1, perlakuan 2 dan perlakuan 3 dapat diketahui bahwa aktivitas enzim lipoprotein lipase mengalami kenaikan yang bermakna.

Ekstrak bawang putih siung tunggal diketahui memilki kandungan antioksidan. Senyawa antioksidan yang terdapat pada ekstrak bawang putih siung tunggal yang dapat meningkatkan aktivitas enzim lipoprotein lipase adalah adanya kandungan flavonoid. Apo C2 merupakan kofaktor dari enzim lipoprotein lipase, yang apabila terjadi gangguan pada Apo C2 ini membuat fungsi dari enzim Lipoprotein Lipase ini terganggu, sehingga kilomikron yang terdiri dari trigliserida terakumulasi didalam darah. Pada kondisi normal, lemak dari makanan yang telah mengalami proses pencernaan menjadi asam lemak bebas, trigliserida, fosfolipid dan kolseterol akan diserap dalam bentuk kilomikron. Kilomikron inilah yang akjan membawa trigliserida kedalam pembuluh darah dan mengalami penguraian oleh enzim lipoprotein lipase sehingga terbentuk asam lemak bebas dan gliserol yang disimpan dalam jaringan adiposa serta sisa-sisa kilomikrondimetabolisme didalam hati (Sloane, 2003; Arauna, 2013).

Flavonoid memiliki ikatan glikosida yang dapat dihidrolisis oleh asam untuk membantu menghentikan reaksi berantai peroksidasi lipid dalam menstabilkan fraksi lipid serta meningkatkan katabolisme VLDL yang merupakan lipoprotein berdensitas sangat rendah yang terdiri atas 60\% trigliserida dan 10-15\% kolesterol. Dengan danya peningkatan enzim lipoprotein lipase, VLDL yang banyak mengandung trigliserida ini mengalami hidrolisis menjadi 
asam lemak dan gliserol (Zang, 2011;

Wang, 2009).

\section{KESIM PULAN}

Berdasarkan hasil penelitian, dapat disimpulkan bahwa pemberian ekstrak bawang putih siung tunggal dapat meningkatkan aktivitas dari enzim lipoprotein lipase

\section{UCAPAN TERIMA KASIH}

Penulis berterima kasih kepada departemen gizi kesehatan masyarakat fakultas kesehatan masyarakat universitas Airlangga, laboratorium biokimia departemen biokimia fakultas kedokteran universitas Airlangga atas bimbingan dan kerjasamanya.

\section{DAFTAR PUSTAKA}

Arauna Y, Aulann'am, dan Oktavianie DA, 2013. Studi kadar trigliserida dan gambaran histopatologis hepar hewan model tikus (Rattus norvegicus) hiperkolesterolemia yang diberi terapi ekstrak air benalu mangga (Dendropthoe pentandra). S. J. Vetschool Unibraw. 2(3): 1-8
Goldberg IJ, Merkel M, 2001. Lipoprotein lipase: physiology, biochemistry, and molecular biology. Frontiers in Bioscience. 6(3): D388-D405

Nafrialdi S, 2007. Farmakologi dan Terapi. Edisi ke-5. Gaya Baru, Jakarta

Pramono A, Kesuma SU, Tazkiana NH, and Yunita RA, 2011. Pengaruh Rebusan Daun Sukun (Artocarpus altilis) Terhadap Kadar Trigliserida, Kolesterol Total dan Low Density Lipoprotein (LDL) Serum Darah Tikus Putih (Rattus norvegicus). Mutiata Medika. 11(3): 139-143

Ramadani IR, Aulanni'am, dan Herawati. 2013. Potensi ekstrak air benalu mangga (Dendrophtoe petandra) terhadap aktivitas enzim lipoprotein lipase (LPL) serum dan histopatologi duodenum hewan model tikus (Rattus norvegicus) hiperkolesterolemia. S. J. Vetschool Unibraw. 2(3): 1-5

Sloane E, 2003. Anatomi dan Fisiologi untuk Pemula. (Diterjemahkan Widyastuti, P). EGC, Jakarta

Wang $\mathrm{H}$ and Eckel $\mathrm{RH}, 2009$. Lipoprotein lipase: From gene to obesity. Am. J. Physiol. Endocrinol. Metab. 297: 271-288

Zang T, Li G, and Mo H, 2011. Persimmon tannin composition and function. Advances in Biomedical Engineering. 1(2): 389-392 